University of Nebraska - Lincoln

DigitalCommons@University of Nebraska - Lincoln

Faculty Publications: Department of

Entomology

Entomology, Department of

2011

Comparative susceptibility of Ostrinia furnacalis, Ostrinia

nubilalis, and Diatraea saccharalis (Lepidoptera: Crambidae) to Bacillus thuringiensis Cry1 toxins

S. Y. Tan

University of Nebraska-Lincoln

B. F. Cayabyab

University of the Philippines Los Baños College

E. P. Alcantara

University of the Philippines Los Baños College

Y. B. Ibrahim

Universiti Pendidikan Sultan Idris, Malaysia

Fangneng Huang

Louisiana State University and Agricultural \& Mechanical College, fhuang@agcenter.Isu.edu

See next page for additional authors

Follow this and additional works at: https://digitalcommons.unl.edu/entomologyfacpub

Part of the Entomology Commons

Tan, S. Y.; Cayabyab, B. F.; Alcantara, E. P.; Ibrahim, Y. B.; Huang, Fangneng; Blankenship, Erin E.; and Siegfried, Blair D., "Comparative susceptibility of Ostrinia furnacalis, Ostrinia nubilalis, and Diatraea saccharalis (Lepidoptera: Crambidae) to Bacillus thuringiensis Cry1 toxins" (2011). Faculty Publications: Department of Entomology. 332.

https://digitalcommons.unl.edu/entomologyfacpub/332

This Article is brought to you for free and open access by the Entomology, Department of at DigitalCommons@University of Nebraska - Lincoln. It has been accepted for inclusion in Faculty Publications: Department of Entomology by an authorized administrator of DigitalCommons@University of Nebraska - Lincoln. 
Authors

S. Y. Tan, B. F. Cayabyab, E. P. Alcantara, Y. B. Ibrahim, Fangneng Huang, Erin E. Blankenship, and Blair D. Siegfried

This article is available at DigitalCommons@University of Nebraska - Lincoln: https://digitalcommons.unl.edu/ entomologyfacpub/332 


\title{
Comparative susceptibility of Ostrinia furnacalis, Ostrinia nubilalis, and Diatraea saccharalis (Lepidoptera: Crambidae) to Bacillus thuringiensis Cry1 toxins
}

\author{
S. Y. Tan, ${ }^{1}$ B. F. Cayabyab, ${ }^{2}$ E. P. Alcantara, ${ }^{3}$ Y. B. Ibrahim, ${ }^{4}$ \\ F. Huang, ${ }^{5}$ E. E. Blankenship, ${ }^{6}$ and B. D. Siegfried ${ }^{1}$ \\ 1. University of Nebraska - Lincoln, Department of Entomology, 202 Entomology Hall, Lincoln, NE 68583 0816, USA \\ 2. National Crop Protection Center, Crop Protection Cluster, Plant and Environmental Health Division, \\ College of Agriculture, University of the Philippines Los Baños College, Laguna 4031, Philippines \\ 3. National Institute of Molecular Biology and Biotechnology, University of the Philippines Los Baños College, Laguna 4031, Philippines \\ 4. Universiti Pendidikan Sultan Idris, Department of Agricultural Science, \\ Faculty of Technical and Vocational Education, Tanjong Malim, Perak 35900, Malaysia \\ 5. Department of Entomology, Louisiana State University Agricultural Center, Baton Rouge, LA 70803, USA \\ 6. Department of Statistics, University of Nebraska-Lincoln, 343B Hardin Hall North, Lincoln, NE 68583 0963, USA \\ Corresponding author - B. D. Siegfried, tel 402 472-8714, fax 402 472-4687, email bsiegfried1@unl.edu
}

\begin{abstract}
Transgenic corn hybrids that express toxins from Bacillus thuringiensis (Bt) are highly effective against the European corn borer, Ostrinia nubilalis (Hübner), and the closely related Asian corn borer, Ostrinia furnacalis (Guenée). Since the registration of Bt corn hybrids in the U.S. in 1996, there has been a great deal of information generated on O. nubilalis. However, relatively little information exists for $O$. furnacalis. To help determine whether the information generated for $O$. nubilalis can be leveraged for decisions regarding the use of transgenic Bt corn against $O$. furnacalis, experiments were designed to determine whether the pattern of sensitivity to various Bt Cry1 toxins is similar between the two species. Test insects included laboratory-reared $O$. furnacalis originating from Malaysia, a Bt-susceptible laboratory colony of O. nubilalis maintained at the University of Nebraska-Lincoln (UNL) and an out-group consisting of the sugarcane borer, Diatraea saccharalis (F.), from Louisiana which represents a different genus from the same family. O. furnacalis and $O$. nubilalis exhibited a similar pattern of susceptibility to all the Cry1 toxins and were highly susceptible to the range of Bt toxins tested including Cry1Aa, Cry1Ab, Cry1Ac and Cry1F. Both of the Ostrinia species were more tolerant to Cry1Ba compared with $D$. saccharalis, although sensitivity of $O$. furnacalis was intermediate and did not differ significantly from that of $O$. nubilalis and D. saccharalis. D. saccharalis was also susceptible to the range of toxins tested but unlike the two Ostrinia species, was more tolerant to Cry1F and more susceptible to Cry1Ba. These results indicate that both of the Ostrinia corn borer species are similar in sensitivity to the Cry1Aa, Cry1Ab, Cry1Ac, Cry1Ba and Cry $1 \mathrm{~F}$ toxins, thus suggesting shared toxin receptors and mechanisms of toxicity for the two species.
\end{abstract}

Keywords: Bacillus thuringiensis, Ostrinia furnacalis, Ostrinia nubilalis, Diatraea saccharalis, Comparative patterns of susceptibility

\section{Introduction}

Since its first introduction in 1996, adoption of genetically modified crops has continued to increase globally with an 80-fold increase in biotech crop area and a total of 134 million ha planted in 2009 (James, 2010). This area is even greater when considering "trait or virtual hectares" which include the area that is planted with single and stacked traits (James, 2010). Of the total biotech crop area, 41.7 million ha (or $31.1 \%$ ) was planted with genetically modified corn in 2009 (James, 2010). The rapid acceptance of this technology has benefited growers with yield increases due to reduction of insect damage especially during moderate and severe infestations (USEPA, 2001). The first Bt corn expressing a Cry1 toxin (Cry1Ab) was introduced in the United States (U.S.) in 1996 and is extremely effective against the
European corn borer, Ostrinia nubilalis (Hübner), one of the most destructive pests in the U.S. Corn Belt (ILSI/HESI, 1998; Mason et al., 1996). Currently, additional Cry toxins have been stacked or pyramided in new events. Cry1 Ab and Cry $1 \mathrm{~F}$ are expressed in both single and pyramided events, while Vip3Aa20, Cry1A.105, and Cry2Ab2 are available only as pyramided traits (USEPA, 2009). Gene pyramiding combines two different Bt Cry proteins with dissimilar target sites and is expected to delay pest resistance more effectively compared to crops that express single Bt toxins (Zhao et al., 2005). In addition to the U.S. which planted 22.2 million ha of Bt corn in 2009 (USDA NASS, 2009), Brazil, Argentina, Canada, South Africa, Uruguay, Spain, Honduras, Chile, Egypt, Romania, Slovakia, Czech Republic, Portugal and the Philippines also plant significant hectarage of $\mathrm{Bt}$ corn (James, 2010). 
A sibling species to O. nubilalis, the Asian corn borer, Ostrinia furnacalis (Guenée), is the most economically important corn stalk boring pest in Asia and is distributed throughout India, Southeast Asia, China, Korea, Japan, Australia, New Guinea, Solomon Islands, and western Micronesia (Lewvanich, 1973; Mutuura and Monroe, 1970). Bt corn (Event MON810) expressing Cry1 Ab was approved for planting in the Philippines to manage $O$. furnacalis in 2002, and the first commercial plantings occurred in early 2003 (James, 2003). Excellent field performance of the Cry1 Ab corn in the Philippines against $O$. furnacalis has been documented and Bt corn hybrids consistently out-yielded conventional hybrids by $41 \%$ in field trials and by $60 \%$ compared with traditional farmer practices (Gonzalez, 2002; James, 2003). The commercial production of MON810 in the Philippines increased rapidly, from only 120 ha in 2002 to 400,000 ha in 2009 (Koul, 2010). In addition to the studies performed in the Philippines, it has been well documented that O. furnacalis is susceptible to Bt corn and Bt cotton that express Cry1Ab or Cry1Ac in China (He et al., 2003a, 2003b). However, the Philippines is so far the only Asian country that plants Bt corn commercially. The Bt events approved for propagation against lepidopteran pests in the Philippines are those that express Cry1Ab (Bureau of Plant Industry, 2010a, 2010b), while Bt events undergoing field trials include those expressing Cry1F and the pyramided events that expresses Cry1A.105, Cry1F, and Cry2Ab (Bureau of Plant Industry, 2010c).

$O$. furnacalis is very similar to O. nubilalis in biology and morphology, and has been frequently misidentified as $O . n u-$ bilalis. A revision of the genus Ostrinia confirmed the status of $O$. furnacalis as a distinct species separate from $O$. nubilalis (Mutuura and Monroe, 1970). Host preferences of O. furnacalis (Caasi-Lit, 2006; Nafus and Schreiner, 1991) and O. nubilalis (Mason et al., 1996) are almost identical. Both prefer corn and share a number of common hosts including cotton, tomato, sorghum, peppers and some beans. Interestingly, both species are found in different parts of China (Zhou et al., 1988). O. furnacalis is the dominant pest in most of the corn growing regions (central to west and southern portions of China) while O. nubilalis predominates in Yining of Xinjiang province and to a lesser extent in Inner Mongolia, Ning Xia, and other areas of northwest China (Zhou et al., 1988).

In view of the success of Bt corn in controlling O. nubilalis in the U.S. and the potential for Bt corn to be adopted in areas where $O$. furnacalis is a major pest, information that has been generated on the Bt corn technology as it relates to O. nubilalis may be useful to regulatory decisions regarding the use of transgenic corn against $O$. furnacalis. In the present study, bioassays were conducted to compare the pattern of susceptibility between $O$. furnacalis and $O$. nubilalis against five Bt Cry1 toxins: Cry1Aa, Cry1Ab, Cry1Ac, Cry1Ba and Cry1F. The sugarcane borer, Diatraea saccharalis (F.), was included in the experiments because it belongs to the same family as Ostrinia species but is taxonomically distant enough to be considered as an out-group. It is also a major corn stalk boring pest in the midsouthern region of the U.S. and South America (Huang et al., 2007). The results of this investigation provide a starting point to determine whether data generated with $O$. nubilalis can be applied to $O$. furnacalis.

\section{Materials and methods}

\subsection{Insects}

A Bt-susceptible colony of O. furnacalis was established from a collection of ca. 300 late instar larvae and pupae obtained from a commercial field in Tanjung Karang, Selangor, Malaysia in June 2008. The colony was maintained in the Department of Crop Protection, University Putra Malaysia, using the standard rearing techniques established for O. nubila- lis (Guthrie et al., 1965; Lewis and Lynch, 1969) as described by Siqueira et al. (2004b), except that a commercial meridic diet (Southland Products Incorporated, Lake Village, AR) was used for larval rearing. A pupation-ring made up of waxedcorrugated-cardboard (Custom Bioproducts, Maxwell, IA) was placed in each larval rearing pan to collect the pupae of $O$. nubilalis. When sufficient number of pupae were obtained, the corrugated-cardboard was transferred into a screened-cage (Bioquip Products, Rancho Dominguez, CA) and eggs were collected daily by using wax papers. A Bt-susceptible $O$. nubilalis colony maintained at the University of Nebraska-Lincoln (UNL) was established from a field collection of ca. 400 larvae from northern Italy. This colony was chosen because it has been maintained in the absence of selection for over 140 generations. Although the colony has been shown to represent both $E$ and $Z$ pheromone races (Marçon et al., 1999a), previous studies have shown that the two strains are similar in susceptibility to Cry1 toxins (Marçon et al., 1999b).

A Bt-susceptible laboratory population of $D$. saccharalis was established from a field collection of $>300$ larvae from non-Bt corn fields near Winnsboro in Franklin Parish, LA during December 2008. A meridic diet specific for D. saccharalis (Southland Products Incorporated, Lake Village, AR) was used for larval rearing. At third instar, larvae were transferred individually into 32-cell rearing trays (Bio-Serv) and provided with $5 \mathrm{ml}$ of diet. Diet was moistened on alternate days until pupation to prevent desiccation. Pupae were transferred from the rearing trays into an oviposition cage. The cage set-up and egg harvesting method were similar to those previously described for O. nubilalis (Marçon et al., 1999b).

\subsection{Bt toxin preparation}

Cry toxins were prepared from fermentation of recombinant Escherichia coli strains transformed to express Cry1Aa (ECE52), Cry1Ab (ECE53), Cry1Ac (ECE54), and Cry1Ba (ECE128) obtained from the Bacillus Genetic Stock Center of the Ohio State University (Columbus, $\mathrm{OH}$ ). The four recombinant $E$. coli cultures were grown at $37^{\circ} \mathrm{C}$ for $48 \mathrm{~h}$ in Terrific broth media (Tartof and Hobbs, 1987) except the Cry1 Ab producing strain which was grown in Luria-Bertani Media. Protoxins were obtained from E. coli fermentation products following the method described by Lee et al. (1992). The solubilized protein was digested with trypsin from bovine pancreas (Sigma-Aldrich ${ }^{\circledR}$ ) and insoluble material was removed by centrifugation. The protoxin preparations were dialyzed against $50 \mathrm{mM} \mathrm{NaCO} / \mathrm{NaHCO}_{3}$ buffer ( $\mathrm{pH}$ 10.0) using Snake$\mathrm{Skin}^{\mathrm{TM}}$ pleated dialysis tubing, $10 \mathrm{k}$ molecular weight cut off (Thermo Scientific, Rockford, IL).

Lyophilized Cry1F toxin was supplied by Dow AgroSciences LLC, Indianapolis, IN. The purified toxin was produced through fermentation of recombinant Pseudomonas fluorescens (Flügge) strain MR872, proteolytically activated and chromatographically purified. Except for the Cry1F toxin which was $13.7 \%$ by weight, other Cry1 toxin preparations were quantified by densitometric quantification (Crespo et al., 2008) of the 60-65 $\mathrm{kDa}$ peptides after sodium dodecyl sulfate-polyacrylamide gel electrophoresis (Laemmli, 1970) and compared to a standard curve for bovine serum albumen (BSA). These endotoxins were lyophilized and stored at $-80^{\circ} \mathrm{C}$.

\subsection{Bioassays}

O. nubilalis and D. saccharalis bioassays were conducted at UNL during March 2008 and May 2009, respectively. Because of quarantine issues, $O$. furnacalis bioassays were conducted in Malaysia at Universiti Putra Malaysia from June-July 2008. Bioassay methods were consistent for both species, and identical toxin preparations were used for all bioassays. Neonates 
of each species ( $<24 \mathrm{~h}$ after eclosion) were exposed to artificial diet (Marçon et al., 2000) in 128-well trays (each well $16 \mathrm{~mm}$ diameter, $16 \mathrm{~mm}$ height, CD International, Pitman, NJ). Approximately $1 \mathrm{ml}$ of diet was dispensed into each well and allowed to solidify. Serial dilutions of seven increasing concentrations were made in $0.1 \%$ Triton- $X 100$ non-ionic detergent $(\mathrm{v} / \mathrm{v})$ to obtain uniform coverage on the diet surface. The diet surface in each well was topically treated with $30 \mu \mathrm{l}$ of the appropriate dilutions. The bioassay diet that was developed for the tobacco budworm, Heliothis virescens (F.), (King et al., 1985) and adapted for O. nubilalis (Marçon et al., 1999b) was used in the bioassays for the three insect species. Control treatments consisted of diet surface treated with $0.1 \%$ Triton X-100 only. Treatments were allowed to air dry, and one neonate was transferred into each well. The wells were covered with vented lids (CD International). Trays for assaying $O$. nubilalis and D. saccharalis were held in an incubator at $27^{\circ} \mathrm{C}, 24 \mathrm{~h}$ scotophase, and $80 \%$ $\mathrm{RH}$. For $O$. furnacalis, bioassays were conducted under ambient laboratory conditions $\left(24-28{ }^{\circ} \mathrm{C}\right.$ and $\left.60-80 \% \mathrm{RH}\right)$. Larval mortality was recorded after $7 \mathrm{~d}$ and included both the number of dead insects and living larvae that had not grown beyond first instar and weighing $\leq 0.1 \mathrm{mg}$ (Marçon et al., 1999b). Therefore, the mortality data combined both death and severe growth inhibition. Control mortality never exceeded 10\%. Bioassays were replicated three to seven times for each combination of insect species and Cry toxin, with 16-32 larvae per replicate.

\subsection{Data analysis}

Probit analyses (Finney, 1971) of the mortality data were performed using POLO-PC (LeOra Software, 2003) to estimate $\mathrm{LC}_{50}$ and $\mathrm{LC}_{90}$ values and the slopes of the dose-response curves. The analyses were performed on both pooled mortality data of individual insect species and Bt Cry toxin and separately on each replication. The latter values were treated as observations from a $3 \times 5$ factorial experimental design and analyzed with a two-way analysis of variance (ANOVA) using the GLMMIX procedure (SAS Institute Inc., 2009). The two main factors were insect species and Bt Cry toxin. ANOVA tests indicated a significant simple interaction between these factors $(P<0.01)$. Comparisons between insect species within each Bt Cry toxins were conducted with a total of 15 combinations. Treatment means were separated using Fisher's LSD at $a=0.05$ level implemented using the LSMEANS option in PROC GLIMMIX (SAS Institute Inc., 2009). To control the experiment-wise Type I error in the interpretation, a Tukey ad- justment for multiple comparisons was applied whereby differences between means were significant at $P<0.05$.

\section{Results}

\subsection{Pooled mortality}

The results of probit regression of pooled dose-response mortality data for the bioassays of the five Bt Cry toxins with neonates of $O$. furnacalis, $O$. nubilalis and $D$. saccharalis are shown in Table 1. For all species, the probit model was a good fit for the mortality data as confirmed by the Pearson Chi-square test for goodness-of-fit (Table 1). O. furnacalis and $O$. nubilalis were highly susceptible to Cry $1 \mathrm{Aa}, \mathrm{Cry} 1 \mathrm{Ab}$, Cry1Ac, and Cry1F. The $\mathrm{LC}_{50}$ values ranged from 1.2 (Cry1Ac) to 13.9 (Cry1F) ng/ $\mathrm{cm}^{2}$ for O. furnacalis and 5.4 (Cry1Ac) to 12.7 (Cry1F) ng/ $\mathrm{cm}^{2}$ for O. nubilalis. However, both corn borer species were more tolerant to Cry1Ba compared to the other Cry toxins with a $\mathrm{LC}_{50}$ value of 24.0 for $O$. nubilalis and $37.2 \mathrm{ng} / \mathrm{cm}^{2}$ for $O$. furnacalis. D. saccharalis was also susceptible to Cry1Aa, Cry1Ab, and Cry1Ac, but unlike the two Ostrinia species, it was significantly more tolerant to Cry1F with a $\mathrm{LC}_{50}$ value of $73.4 \mathrm{ng} / \mathrm{cm}^{2}$ and more susceptible to Cry1Ba $\left(\mathrm{LC}_{50}=12.5 \mathrm{ng} / \mathrm{cm}^{2}\right)$.

\subsection{Patterns of susceptibility}

The overall pattern of susceptibility among the three species is described in Figure 1. Both O. furnacalis and O. nubilalis exhibited a similar pattern of susceptibility in terms of the relative $L_{50}$ values. In most cases, the $D$. saccharalis response was similar to that of the two corn borer species, except that an inverse relationship was observed with respect to the relative $\mathrm{LC}_{50}$ values for Cry1Ba and Cry1F. O. furnacalis and O. nubilalis were more tolerant of Cry1Ba relative to $D$. saccharalis, while D. saccharalis was more tolerant to Cry1F. In general, the slopes for probit regressions of $O$. nubilalis mortality were steeper than those observed with $O$. furnacalis and $D$. saccharalis. This may reflect reduced genetic variability in the lab colony of $O$. nubilalis as a result of long-term lab rearing relative to the other two species.

Patterns of the susceptibility were analyzed using ANOVA, and the interaction between insect species by $\mathrm{Bt}$ toxins was significant $(F=18.99 ; \mathrm{df}=36 ; P=<0.0001)$. Therefore, the simple interactions between insect species within each Bt toxin were examined. Individual comparisons between Cry1 toxins were

Table 1. Lethal concentrations of five Bacillus thuringiensis Cry1 toxins to Ostrinia furnacalis, O. nubilalis and Diatraea saccharalis with Probit analyses on combined mortality data.

\begin{tabular}{|c|c|c|c|c|c|c|c|}
\hline Insect species & Cry toxin & $\mathrm{n}^{\mathrm{a}}$ & Slope (SE) & $\mathrm{LC}_{50}(95 \% \mathrm{FL})^{\mathrm{b}}$ & $\mathrm{LC}_{90}(95 \% \mathrm{FL})^{\mathrm{b}}$ & $x^{2 c}$ & df \\
\hline \multirow[t]{5}{*}{ Ostrinia furnacalis } & Cry1Aa & 770 & $2.1(0.1)$ & $10.7(9.3-12.3)$ & $44.2(36.3-56.1)$ & 0.7 & 4 \\
\hline & Cry1Ab & 1009 & $1.7(0.1)$ & $4.0(3.4-4.8)$ & 23.9 (19.4-30.8) & 4.4 & 5 \\
\hline & Cry1Ac & 667 & $1.4(0.1)$ & $1.2(0.9-1.6)$ & $10.7(8.3-14.8)$ & 2.8 & 5 \\
\hline & Cry1Ba & 1020 & $3.1(0.3)$ & $24.0(21.3-26.8)$ & $62.0(53.8-74.1)$ & 3.1 & 5 \\
\hline & Cry1F & 669 & $2.4(0.2)$ & $13.9(12.0-15.9)$ & 47.5 (39.4-59.9) & 1.8 & 4 \\
\hline \multirow[t]{5}{*}{ Ostrinia nubilalis } & Cry1Aa & 781 & $2.3(0.2)$ & $9.6(8.3-11.0)$ & $34.1(28.3-43.0)$ & 3.7 & 4 \\
\hline & Cry $1 \mathrm{Ab}$ & 890 & $2.5(0.2)$ & $11.5(9.1-14.0)$ & $37.4(28.9-54.6)$ & 5.1 & 4 \\
\hline & Cry1Ac & 754 & $2.6(0.2)$ & $5.4(4.7-6.1)$ & 16.1 (13.6-19.8) & 2.1 & 5 \\
\hline & Cry1Ba & 478 & $5.4(0.7)$ & $37.2(33.3-41.1)$ & $64.0(56.5-76.9)$ & 1.7 & 3 \\
\hline & Cry $1 F$ & 379 & $2.8(0.3)$ & $12.7(9.1-17.2)$ & $35.9(25.2-64.9)$ & 3.9 & 3 \\
\hline \multirow[t]{5}{*}{ Diatraea saccharalis } & Cry1Aa & 764 & $1.9(0.1)$ & $5.6(4.6-6.7)$ & $26.9(21.0-36.6)$ & 3.2 & 5 \\
\hline & Cry1Ab & 670 & $1.7(0.1)$ & $10.4(8.3-12.9)$ & 61.7 (46.9-87.0) & 1.4 & 4 \\
\hline & Cry1Ac & 575 & $1.8(0.1)$ & $2.8(1.7-4.4)$ & $14.8(8.4-39.3)$ & 6.0 & 3 \\
\hline & Cry1Ba & 574 & $1.8(0.2)$ & $12.5(6.2-20.5)$ & $66.0(38.3-173.6)$ & 5.4 & 3 \\
\hline & Cry1F & 480 & $1.5(0.2)$ & $73.4(35.2-163.3)$ & $546.5(217.6-14691.0)$ & 5.0 & 3 \\
\hline
\end{tabular}

a. Total number of larvae tested in bioassay.

b. ng of Cry toxin/ $\mathrm{cm}^{2}$ of treated artificial diet surface with $95 \%$ fiducial limits in parentheses.

c. $X^{2}$ values from the goodness-of-fit test indicate a significant $(P<0.05)$ fit of the probit model. 

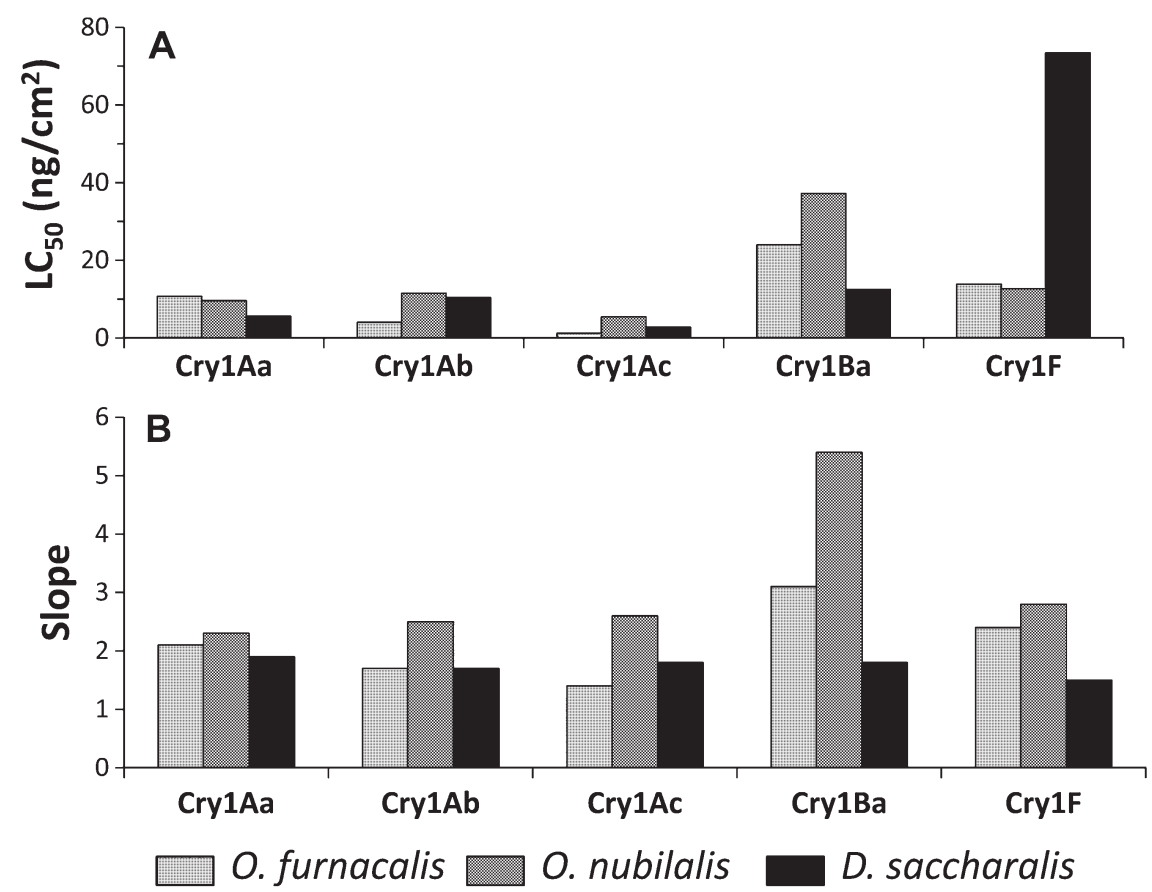

Figure 1. $\mathrm{LC}_{50}(\mathrm{~A})$ and slope of probit regressions (B) for O. furnacalis, O. nubilalis and D. saccharalis against five Bt Cry1 toxins.

not reported because we were interested only in comparing the insect species among the Bt toxins tested. Table 2 indicates that out of 15 pairwise comparisons, significant differences $(P<0.05)$ were observed with Cry1Ba and Cry1F toxins. O. $n u-$ bilalis $\left(\mathrm{LC}_{50}=37.88 \mathrm{ng} / \mathrm{cm}^{2}\right.$ ) was significantly less susceptible (3-fold) to Cry1Ba compared to D. saccharalis $\left(\mathrm{LC}_{50}=12.98 \mathrm{ng} /\right.$ $\left.\mathrm{cm}^{2}\right)$. The sensitivity of $O$. furnacalis $\left(\mathrm{LC}_{50}=24.0 \mathrm{ng} / \mathrm{cm}^{2}\right)$ to Cry1Ba was intermediate between $O$. nubilalis and D. saccharalis, and the pairwise comparisons were not significantly different $(0.0255$ and 0.554 respectively at $P>0.05)$. Cry1F was 5 -fold more toxic towards both Ostrinia species (O. furnacalis: $\mathrm{LC}_{50}=17.15 ;$ O. nubilalis: $\mathrm{LC}_{50}=18.09 \mathrm{ng} / \mathrm{cm}^{2}$ ) compared to $D$. saccharalis $\left(\mathrm{LC}_{50}=78.14 \mathrm{ng} / \mathrm{cm}^{2}\right)$. None of the pairwise comparisons of $\mathrm{LC}_{90}$ values were significantly different except for the differences between both Ostrinia species and D. saccharalis when exposed to $\operatorname{Cry} 1 \mathrm{~F}(P<0.05)$.

\section{Discussion}

The results presented here provide the first comparison of susceptibility to Bt toxins between $O$. nubilalis and $O$. furnacalis. Although the two species were bioassayed at different times and in different laboratories, the materials and methods were kept as similar as possible to enable comparison between insect species. D. saccharalis was used as a positive control where differences in the pattern of susceptibility among the

Table 2. Simple effect comparisons between insect species among the five $\mathrm{Bt}$ toxins at $\mathrm{LC}_{50}$ and $\mathrm{LC}_{90}$ values.

\begin{tabular}{|c|c|c|c|c|c|c|}
\hline $\begin{array}{l}\text { Bt toxins and } \\
\text { comparisons }^{\mathrm{a}}\end{array}$ & $\begin{array}{l}\mathrm{LC}_{50}(\mathrm{SE}) \\
\text { Insect species } 1\end{array}$ & Insect species 2 & $\operatorname{Pr}>|\mathrm{t}|^{\mathrm{b}}$ & $\begin{array}{l}\mathrm{LC}_{90}(\mathrm{SE}) \\
\text { Insect species } 1\end{array}$ & Insect species 2 & $\operatorname{Pr}>|\mathrm{t}|^{\mathrm{b}}$ \\
\hline \multicolumn{7}{|l|}{ Cry1Aa } \\
\hline Of $\times$ On & $10.66(3.53)$ & $9.77(4.07)$ & 0.9448 & $44.7(72.7)$ & $30.8(83.9)$ & 0.9915 \\
\hline $\mathrm{On} \times \mathrm{Ds}$ & $9.77(4.07)$ & $5.54(4.07)$ & 0.7448 & $30.8(83.9)$ & $27.2(83.9)$ & 0.9755 \\
\hline \multicolumn{7}{|l|}{ Cry1Ab } \\
\hline Of $\times$ On & $3.76(3.53)$ & $12.06(4.07)$ & 0.2848 & $24.2(72.7)$ & $37.6(83.9)$ & 0.9995 \\
\hline Of $\times$ Ds & $3.76(3.53)$ & $12.64(4.07)$ & 0.2396 & $24.2(72.7)$ & $108.8(83.9)$ & 0.7283 \\
\hline Of $\times$ On & $2.42(2.67)$ & $5.43(4.99)$ & 0.8567 & $13.4(55.0)$ & 16.1(102.8) & 0.9997 \\
\hline Of $\times$ Ds & $2.42(2.67)$ & $3.35(4.07)$ & 0.9803 & 13.4(55.0) & $25.8(83.9)$ & 0.9916 \\
\hline On $\times$ Ds & $5.43(4.99)$ & $3.35(4.07)$ & 0.9443 & $16.1(102.8)$ & $25.8(83.9)$ & 0.9970 \\
\hline \multicolumn{7}{|l|}{ Cry1Ba } \\
\hline Of $\times$ On & $23.65(3.53)$ & $37.88(4.99)$ & 0.0642 & 72.7(72.7) & 66.1(102.8) & 0.9985 \\
\hline Of $\times$ Ds & $23.65(3.53)$ & $12.98(4.07)$ & 0.1391 & $72.7(72.7)$ & $66.0(83.9)$ & 0.9980 \\
\hline On $\times$ Ds & $37.88(4.99)$ & $12.98(4.07)$ & 0.0013 & 66.1(102.8) & $66.0(83.9)$ & 1.0000 \\
\hline
\end{tabular}

a. Pairwise comparisons between 2 insect species with LSMeans where $O f$, On and Ds represent O. furnacalis, O. nubilalis and D. saccharalis respectively.

b. $\mathrm{LC}_{50}$ and $\mathrm{LC}_{90}$ values are not significantly different when $P>0.05$. 
Bt toxins are more likely given the greater taxonomic distance between the two genera, and thus increasing the sensitivity of the analyses. In general, $D$. saccharalis grew more slowly compared to both Ostrinia species on the bioassay diet which may indicate that the diet composition is less suitable for this species relative to the two Ostrinia species. However, similar feeding behavior was observed among these three insect species in that initial feeding involved scraping the diet surface before tunneling it. This suggests a similar uptake of the Bt Cry toxins. In addition, all control mortality was less than $10 \%$ which confirms the response to $\mathrm{Bt}$ toxin exposure in all species.

Cry1Aa, Cry1Ab, and Cry1Ac toxins were very active against all three species and their sensitivity was not significantly different between species at $\mathrm{LC}_{50}$ and $\mathrm{LC}_{90}$ values (Table 2). In general, Cry1Ac was more active than Cry1Ab for both Ostrinia species which contrasts with previous results for $O$. nubilalis in which Cry1 Ab has been reported as being more toxic than Cry1Ac (Denolf et al., 1993). Cry1Ac might be more active compared to Cry1Ab because the recombinant $E$. coli that expressed Cry1Ac was grown in a different media. Nutrient broth variation used for fermentation and crystal-harvesting time could influence the levels of attached sugars, a product of non-enzymatic glycosylation, which may in turn affect the specificity and toxicity of the crystals produced (Bhattacharya et al., 1993).

Interestingly, Cry1Ba and Cry1F appeared to exhibit contrasting patterns of toxicity in the two corn borer species compared with $D$. saccharalis. Cry1Ba was less toxic to O. nubilalis $\left(\mathrm{LC}_{50}=37.88 \mathrm{ng} / \mathrm{cm}^{2}\right)$ than O. furnacalis $\left(\mathrm{LC}_{50}=23.65 \mathrm{ng} /\right.$ $\mathrm{cm}^{2}$ ), and was significantly more toxic to $D$. saccharalis $\left(\mathrm{LC}_{50}=12.98 \mathrm{ng} / \mathrm{cm}^{2}\right)(P<0.05)$ (Table 2$)$. The low Cry1Ba toxicity observed in both Ostrinia species is similar to results from bioassays of other lepidopterans including $H$. virescens (Karlova et al., 2005), Spodoptera exigua (Hübner) (de Maagd et al., 2000) and Manduca sexta (Linnaeus) (Bradley et al., 1995) which all exhibited relatively low susceptibility. It was reported that trypsin activity against Domain I during Cry1Ba production and activation generated a less active $55 \mathrm{kDa}$ protein that may have decreased the toxicity (de Maagd et al., 2000). In general, both Ostrinia species were more tolerant to Cry1Ba compared to D. saccharalis. In contrast, Cry1F was significantly more toxic to both Ostrinia species than to $D$. saccharalis ( Table 1 \& Table 2 ).

The slopes of probit regressions for all toxins tested against $O$. nubilalis were steeper than those for $O$. furnacalis and $D$. saccharalis. The steeper slopes are indicative of a genetically homogeneous population (Eaton and Klaassen, 2001) and are not unexpected for a laboratory colony which in this case had been inbred for 141 generations. Although O. nubilalis exhibited higher slopes for response curves, the pattern of susceptibility to the Cry toxins tested was similar to $O$. furnacalis.

In general, the high sensitivity of both Ostrinia species towards Cry1 toxins shown in this study concurs with previous reports for O. nubilalis (Chaufaux et al., 2001; Crespo, 2008; Marçon et al., 1999b; Siqueira et al., 2004a) and O. furnacalis (He et al., 2005; Wen et al., 2005). However, our results indicate that Cry1Ba is less toxic to O. nubilalis compared to the Cry1A toxins, while $\mathrm{Li}$ et al. (2005) reported that a susceptible strain of O. nubilalis was equally sensitive to Cry1Aa, Cry1Ab, Cry1Ac and Cry1Ba, although different exposure methods were used. In addition, our results suggest similar susceptibility to Cry $1 \mathrm{Ab}$ among the three species. However, Huang et al. (2006) reported D. saccharalis was 10 -fold more tolerant to Cry1Ab than either laboratory or field strains of $O$. nubilalis. Such differences might have occurred due to differences in toxin sources (corn leaf tissue vs. toxin preparations from recombinant E. coli strains) as well as the differences in exposure methods (surface-treated diet vs. diet incorporation). It is ap- parent from these conflicting results that direct comparisons of bioassay results using different methods and sources of toxins should be avoided. Importantly, field populations of $O$. nubilalis remain susceptible after more than a decade since Bt corn introduction (Siegfried et al., 1995, 2007). Similarly, excellent field control on the O. furnacalis has been demonstrated in combinations of field evaluations and laboratory bioassays using plant tissues of corn expressing Cry1Ab (He et al., 2003a, 2003b; Wen et al., 2005) and cotton expressing Cry1A, Cry1A and CpTI, Cry1Ac, Cry1le (He et al., 2004, 2006; Song et al., 2003).

In general, these results provide strong evidence of similarity in sensitivity patterns between both Ostrinia species towards Cry1Aa, Cry1Ab, Cry1Ac, and Cry1F toxins which suggests a common target site among the two species and potentially common resistance mechanisms that might evolve in response to selection from Bt corn. Documenting this similarity may assist regulatory agencies in Asia to leverage existing data sets that have been developed for resistance management of $O$. nubilalis in North America for decisions regarding registration, regulation, cultivation, and resistance management of $O$. furnacalis. However, deployment of transgenic corn against $O$. furnacalis will need to consider other factors such as the differences in biology and ecology of two species, as well as differences in maize cultivation systems.

Acknowledgments - We thank Mr. Terence Spencer for support with the bioassays procedures; Dow AgroSciences LLC for their permission to use the proprietary activated Cry1F; Mr. Gait Fee Chung and Dr. Kok Eng Ooi for their assistance in the pesticide import permit application in Malaysia; various students, staff, and faculty in the Plant Protection Department of Agriculture Hall in Universiti Putra Malaysia for using their facilities. This research was supported by the United States of America International Development Program for Biosafety and Pioneer Hi-Bred International Inc.

\section{References}

Bhattacharya, M., Plantz, B.A., Swanson-Kobler, J.D., Nickerson, K.W. 1993. Nonenzymatic glycosylation of lepidopteran-active Bacillus thuringiensis protein crystals. Appl. Environ. Microbiol. 59, 2666-2672.

Bradley, D., Harkey, M.A., Kim, M.K., Brever, D., Bauer, L.S., 1995. The insecticidal Cry1B protein of Bacillus thuringiensis species thuringiensis has dual specificity to coleopteran and lepidopteran larvae. J. Invertebr. Pathol. 65, 162-173.

Bureau of Plant Industry, Philippines, 2010a. ANNEX II: Approval Registry of Regulated Articles for Propagation. 1. http://www.biotech. da.gov.ph/Approval Registry.php (accessed April 26, 2010).

Bureau of Plant Industry, Philippines, 2010b. ANNEX IIA: Approval Registry for Propagation of Combined Trait Products, 1 pp. http:// www.biotech.da.gov.ph/Approval_Registry.php (accessed April 26, 2010).

Bureau of Plant Industry, Philippines, 2010c. ANNEX IV: Approval Registry of Regulated Articles for Field Trial, $5 \mathrm{pp}$. http://www.biotech. da.gov.ph/Approval Registry.php (accessed April 26, 2010).

Caasi-Lit, M.T., 2006. Bt Corn and Potential Alternate Host Plants of the Asian Corn Borer. Biotechnology Information Center. 2. SEARCA, Philippines. http://www.bic.searca.org/info kits/btcorn host.pdf (accessed April 26, 2010).

Chaufaux, J., Seguin, M., Swanson, J.J., Bourguet, D., Siegfried, B.D. 2001. Chronic exposure of the European corn borer (Lepidoptera: Crambidae) to Cry1 Ab Bacillus thuringiensis toxin. J. Econ. Entomol. 94, 1564-1570.

Crespo, A.L.B., 2008. Characterization of resistance to the Cry1Ab toxin from Bacillus thuringiensis Berliner in a field-derived strain of European corn borer, Ostrinia Nubilalis (Hübner) (Lepidoptera: Crambidae). PhD Dissertation, University of Nebraska-Lincoln, USA. 158 pp.

Crespo, A.L.B., Spencer, T.A., Nekl, E., Pusztai-Carey, M., Moar, W.J., Siegfried, B.D., 2008. Comparison and validation of methods to quantify Cry1Ab toxin from Bacillus thuringiensis for standardization of insect bioassays. Appl. Environ. Microbiol. 74, 130-135. 
de Maagd, R.A., Weemen-Hendriks, M., Stiekema, W., Bosch, D., 2000. Bacillus thuringiensis delta-endotoxin Cry1C domain III can function as a specificity determinant for Spodoptera exigua in different, but not all, Cry1-Cry1C hybrids. Appl. Environ. Microbiol. 66, 1559-1563.

Denolf, P., Jansens, S., Peferoen, M., Degheele, D., Van Rie, J., 1993. Two different Bacillus thuringiensis delta-endotoxin receptors in the midgut brush border membrane of the European corn borer, Ostrinia nubilalis (Hübner) (Lepidoptera: Pyralidae). Appl. Environ. Microbiol. $59,1828-1837$.

Eaton, D.L., Klaassen, C.D., 2001. Principles of toxicology. In: Klaassen, C.D. (Ed.), Casarett and Doull's Toxicology: The Basic Science of Poisons. The McGraw-Hill Companies, Inc., USA, pp. 11-34.

Finney, D.J., 1971. Probit Analysis. Cambridge University Press, London, England.

Gonzalez, L.A., 2002. Likely Transcendental Effects of Agri-biotechnology. The Case of Bt Hybrid Corn in the Philippines. Symposium on Bt Technology: Facts Issues, 5 May 2002. STRIVE Foundation, Los Baños, Laguna, Philippines.

Guthrie, W.D., Raun, E.S., Dicke, F.F., Pesho, G.R., Carter, S.W., 1965. Laboratory production of European corn borer egg masses. Iowa J. Sci. 40, 665-683.

He, K.L., Wang, Z.Y., Wen, L.P., Bai, S.X., Zhou, D.R., Zhu, Q.R., 2003a. Field evaluation of the Asian corn borer control in hybrid of transgenic maize event MON810. Agric. Sci. China 2, 1363-1368.

He, K.L., Wang, Z.Y., Zhou, D.R., Wen, L.P., Song, Y.Y., Yao, Z.Y., 2003 b. Evaluation of transgenic Bt corn for resistance to the Asian corn borer (Lepidoptera: Pyralidae). J. Econ. Entomol. 96, 935-940.

He, K.L., Wang, Z., Bai, S., Zheng, L., Wang, Y., 2004. Field efficacy of transgenic cotton containing single and double toxin genes against the Asian corn borer (Lepidoptera: Pyralidae). J. Appl. Entomol. 128, $710-715$.

He, K., Wang, Z., Wen, L.P., Bai, S.X., Ma, X., Yao, Z., 2005. Determination of baseline susceptibility to Cry1Ab protein for Asian corn borer (Lepidoptera: Crambidae). J. Appl. Entomol. 129, 407-412.

He, K.L., Wang, Z.Y., Bai, S.X., Zheng, L., Wang, Y.B., Cui, H.Y., 2006. Efficacy of transgenic Bt cotton for resistance to the Asian corn borer (Lepidoptera: Crambidae). Crop Prot. 25, 167-173.

Huang, F., Leonard, B.R., Gable, R.H., 2006. Comparative susceptibility of European corn borer, southwestern corn borer, and sugarcane borer (Lepidoptera: Crambidae) to Cry1 Ab protein in a commercial Bacillus thuringiensis corn hybrid. J. Econ. Entomol. 99, 194-202.

Huang, F., Leonard, B.R., Andow, D.A., 2007. Sugarcane borer resistance to transgenic Bacillus thuringiensis-maize. J. Econ. Entomol. 100, 164-171.

ILSI/HESI (International Life Sciences Institute/Health and Environmental Sciences Institute), 1998. An Evaluation of Insect Resistance Management in Bt Field Corn: A Science-based Framework for Risk Assessment and Risk Management. Report of an Expert Panel. ILSI Press, Washington, DC, 78 pp.

James, C., 2003. Global Review of Commercialized transgenic crops: 2002 Feature: Bt maize. ISAAA Briefs No. 29. International Service for the Acquisition of Agribiotech Applications, Ithaca, NY, 182 pp.

James, C., 2010. Executive summary of global status of commercialized biotech/GM crops: 2009. The First Fourteen Years, 1996 to 2009. In: ISAAA Briefs No. 41. International Service for the Acquisition of Agri-biotech Applications. Ithaca, , NY.

Karlova, R., Weemen-Hendriks, M., Naimov, S., Ceron, J., Dukiandjiev, S., de Maagd, R.A., 2005. Bacillus thuringiensis $\delta$-endotoxin Cry1Ac domain III enhances activity against Heliothis virescens in some, but not all Cry1-Cry1Ac hybrids. J. Invertebr. Pathol. 88, 169-172.

King, E.G., Hartley, G.G., Martin, D.F., Laster, M.L., 1985. Large-scale rearing of a sterile backcross of the tobacco budworm Heliothis virescens (Lepidoptera: Noctuidae). J. Econ. Entomol. 78, 1166-1172.

Koul, R., 2010. Philippines grows a success story out of bt corn. BioSpectrum. http://www.biospectrumasia.com/ Content/200110PHL11844.asp (accessed April 26, 2010).

Laemmli, U.K., 1970. Cleavage of structural proteins during the assembly of the head of bacteriophage T4. Nature 227, 680-685.

Lee, M.K., Milne, R.E., Ge, A.Z., Dean, D.H., 1992. Location of a Bombyx mori receptor binding region on a Bacillus thuringiensis delta-endotoxin. J. Biol. Chem. 267, 3115-3121.

LeOra Software, 2003. POLO-PC: a User's Guide to Probit and Logit Analysis. Berkeley, CA.

Lewis, L.C., Lynch, R.E., 1969. Rearing the European corn borer on corn leaf and wheat germ diets. Iowa J. Sci. 44, 9-14.
Lewvanich, A., 1973. Study of the identity of the corn stem borer in Thailand. Thai J. Agric. Sci. 7, 103-109.

Li, H., Oppert, B., Higgins, R.A., Huang, F., Buschman, L.L., Zhu, K.Y., 2005. Susceptibility of Dipel-resistant and -susceptible Ostrinia nubilalis (Lepidoptera: Crambidae) to individual Bacillus thuringiensis protoxins. J. Econ. Entomol. 98, 1333-1340.

Marçon, P.C.R.G., Siegfried, B.D., Spencer, T., Hutchison, W.D., 2000. Development of diagnostic concentrations for monitoring Bacillus thuringiensis resistance in European corn borer (Lepidoptera: Crambidae). J. Econ. Entomol. 93, 925-930.

Marçon, P.C.R.G., Taylor, D.B., Mason, C.E., Hellmich, R.L., Siegfried, B.D., 1999a. Genetic similarity among pheromone and voltinism races of Ostrinia nubilalis (Hübner) (Lepidoptera: Crambidae). Insect Mol. Biol. 8, 213-221.

Marçon, P.C.R.G., Young, L.G., Steffey, K.L., Siegfried, B.D., 1999b. Baseline susceptibility of European corn borer (Lepidoptera: Crambidae) to Bacillus thuringiensis toxins. J. Econ. Entomol. 92, 279-285.

Mason, C.E., Rice, M.E., Calvin, D.D., Van Duyn, J.W., Showers, W.B. Hutchinson, W.D., Witkowski, J.F., Higgins, R.A., Onstad, D.W., Dively, G.P., 1996. European Corn Borer Ecology and Management. Iowa State University. North Central Regional Publication, Publication 327, Ames. 57.

Mutuura, A., Monroe, E., 1970. Taxonomy and distribution of the European corn borer and allied species: genus Ostrinia (Lepidoptera: Pyralidae). Memoirs Entomol. Soc. Can., 71.

Nafus, D.M., Schreiner, I.H., 1991. Review of the biology and control of the Asian corn borer, Ostrinia furnacalis (Lepidoptera: Pyralidae). Trop. Pest Manag. 37, 41-56.

SAS Institute Inc., 2009. SAS/STAT: 9.2 User's Guide Second Edition. SAS Institute Inc, Cary, NC.

Siegfried, B.D., Marçon, P.C.R.G., Witkowski, J.F., Wright, R.J., Warren, G.W., 1995. Susceptibility of field populations of the European corn borer, Ostrinia nubilalis (Hübner) (Lepidoptera: Pyralidae), to Bacillus thuringiensis (Berliner). J. Agric. Entomol. 12, 267-273.

Siegfried, B.D., Spencer, T., Crespo, A.L., Storer, N.P., Head, G.P., Owens, E.D., Guyer, D., 2007. Ten years of monitoring for Bt resistance in the European corn borer: What we know, what we don't know and what we can do better. Am. Entomol. 53, 208-214.

Siqueira, H.A.A., Moellenbeck, D., Spencer, T., Siegfried, B.D., 2004a. Cross-resistance of Cry1Ab-selected Ostrinia nubilalis (Lepidoptera: Crambidae) to Bacillus thuringiensis d-endotoxins. J. Econ. Entomol. 97, 1049-1057

Siqueira, H.A.A., Nickerson, K.W., Moellenbeck, D., Siegfried, B.D., 2004b. Activity of gut proteinases from Cry1Ab-selected colonies of the European corn borer, Ostrinia nubilalis (Lepidoptera: Crambidae). Pest Manag. Sci. 60, 1189-1196.

Song, F., Zhang, J., Gu, A., Wu, Y., Han, L., He, K., Chen, Z., Yao, J., Hu, Y., Li, G., Huang, D., 2003. Identification of cry1I-type genes from $B a-$ cillus thuringiensis strains and characterization of a novel cry1I-type gene. Appl. Environ. Microbiol. 69, 5207-5211.

Tartof, K.D., Hobbs, C.A., 1987. Improved media for growing plasmid and cosmid clones. Bethesda Res. Lab. Focus 9, 12.

USEPA (United States Environmental Protection Agency), 2001. Bt plant- Incorporated Protectants October 15, 2001. Biopesticides registration Action Document. http://www.epa.gov/pesticides/biopesticides/pips/bt brad.htm (accessed April 26, 2010).

USEPA (United States Environmental Protection Agency), 2009. Current and Previously Section 3 PIP Registrations. http://www.epa. gov/pesticides/biopesticides/pips/pip list.htm (accessed April 26, 2010).

USDA NASS, 2009. United States Department of Agriculture. National Agricultural Statistical Services, Acreage. http:/ /jan.mannlib.cornell. edu/usda/current/Acre/Acre-06-30-2009.pdf (accessed October 28, 2010).

Wen, L.P., He, K.L., Wang, Z.Y., Zhou, D.R., Bai, S.X., 2005. Susceptibility of Ostrinia furnacalis to Bacillus thuringiensis and Bt corn under long-term laboratory selection. Agric. Sci. China 4, 125-133.

Zhao, J.-Z., Cao, J., Collins, H.L., Bates, S.L., Roush, R.T., Earle, E.D., Shelton, A.M., 2005. Concurrent use of transgenic plants expressing a single and two Bacillus thuringiensis genes speeds insect adaptation to pyramided plants. Proc. Natl. Acad. Sci. USA 102, 8426-8430.

Zhou, D.R., Wang, Y.S., Li, W.D., 1988. Studies on the identification of the dominant corn borer species in China. Acta Phytophylacica Sinica 15, 145-152 (In Chinese with English Abstract). 